\title{
Quantitative specific antigen determination using fluorescent antibody ${ }^{1}$
}

\author{
ROBERT L. NUTTER AND PAUL WOODRUFF \\ From the Department of Microbiology, Loma Linda University, Loma Linda, \\ California, U.S.A.
}

SYNOPSIS A technique is described for the quantitation of a specific protein in the presence of other proteins. The application of this method to the assay of bacteriophage $T_{2}$ coat protein is presented and discussed.

In the process of a study of multiplicity reactivation with $T_{2}$ bacteriophages in our laboratory, a sensitive assay for $T_{2}$ coat protein in the presence of other proteins was considered to be desirable. The technique which was developed to accomplish this was first applied to the simple infection of Escherichia coli $\mathrm{B}$ by $\mathrm{T}_{2} \mathrm{r}+$ bacteriophages. The description of this technique and the results of this particular experiment form the body of this report. The application of the technique to multiplicity reactivation studies will be reported separately in connexion with other reactivation experiments.

The detection of antigen by immunofluorescent techniques has been widely employed for the localization in tissue and cells of specific antigens. This has been particularly pronounced since the work of Coons and Kaplan (1950). Because of the relative specificity of this qualitative method, it was considered as a basis for the development of a simple quantitative technique for specific protein assay even in the presence of other antigenic materials including other proteins. In addition, fluorescent materials may be detected in low concentrations by means of readily available instruments for spectrofluorometry.

The quantitative precipitin technique is well known as an analytical method for the estimation of antigen or antibody. With micro Kjeldahl methods for nitrogen determination, it has been shown that a linear relationship exists between antigen $\mathrm{N}$ precipitated and antigen added in the region of antibody excess. In the development of the technique reported here, under similar conditions, a linear relationship between the amount of fluoresc-

${ }^{1}$ This work was supported by grants from the National Science Foundation and a medical student fellowship (N.I.H.) to one of us (P.W.)

Received for publication 12 June 1965. ence and the amount of specific antigen present was found to exist. The specific antigen in this case was bacteriophage $T_{2}$ coat protein. Whole infectious bacteriophages of known concentration were used, which made possible a standardization of the amount of fluorescence in terms of $T_{2}$ concentration. The application of this technique to a simple $T_{2}$ infection experiment has yielded results which fit in well with those of previous experiments.

\section{METHODS}

PREPARATION OF IMMUNE SERA The antigen was prepared in an adjuvant mixture according to Freund's techniques and preserved with a $1: 10,000$ concentration of merthiolate.

Young albino rabbits were inoculated intramuscularly at weekly intervals for three weeks with $1 \mathrm{ml}$. injections of mixture, and were bled seven days after the final injection. The serum was separated from the clot and centrifuged if necessary to free it from red blood cells. A qualitative test for antibody was made using the precipitin ring test. Those sera which had the highest antibody concentration were chosen for the experiment and were stored frozen until use.

SEPARATION OF GAMMA GLOBULIN FRACTION The gamma globulin fractions containing the antibody were separated from the other serum protein fractions by methanol precipitation at temperatures below $0^{\circ} \mathrm{C}$ (Dubert, Slizewicz, Rebeyrotte, and Macheboeuf, 1953).

Determination of PROTEIN CONCENTRATION Protein concentrations in the gamma globulin fraction were determined by the Biuret method or by the method of Lowry, Rosebrough, Farr, and Randall (1951). Treated fluorescent conjugate (method of preparation follows) was diluted to a protein concentration of approximately $5 \mathrm{mg} . / \mathrm{ml}$.

CONJUGATION OF GAMMA GLOBULINS WITH FLUORESCEIN ISOTHIOCYANATE The tagging of the gamma globulins 
with fluorescein was done using fluorescein isothiocyanate (Riggs, Seiwald, Burckhalter, Downs, and Metcalf, 1958) on Celite (Nutritional Biochemicals Corp.). In order to free the preparation from unbound fluorescein isothiocyanate, dialysis in the cold against buffered saline $(p \mathrm{H} 7)$ was employed. Later, however, this treatment was discontinued and the unbound fluorescein isothiocyanate was separated using gel filtration techniques with Sephadex G-50 medium-grain dextran gel (Pharmacia Fine Chemicals, Inc.).

ADSORPTION OF NON-SPECIFIC CONJUGATES In order to minimize non-specific fluorescence, the conjugate mixture was incubated for one hour at room temperature with a finely-ground tissue suspension not containing the specific antigen, but likely to be associated with it. In the case of viral proteins as specific antigens, the host cells for these viruses were found to remove non-specific labelled materials from the fluorescent antibody preparation.

GROWTH OF MICROORGANISMS The bacteriophage $\mathrm{T}_{2} \mathrm{r}+$ grown in Escherichia coli B as host cell was employed in the study. For the preparation of bacteriophage stocks, the bacteria were grown in a medium containing casamino acids and glycerol (Fraser and Jerrel, 1953) to a concentration of $2 \times 10^{\circ}$ per ml. at which time the bacteriophages were added with a phage to bacterium ratio of $1: 10$. After lysis of the bacteria, the bacteriophages were purified by treatment with D.N.A.-se, filtration, and differential centrifugation.

PHAGE ASSAY The agar layer method as given by Adams (1950) was used to assay the bacteriophage.

\section{RESULTS}

EXPERIMENT USING PURIFIED BACTERIOPHAGE In order to test the procedure with a simple system, coat protein of $\mathrm{T}_{2} \mathrm{r}+$ was chosen as a trial antigen. Purified $\mathrm{T}_{2} \mathrm{r}+$ at $3 \times 10^{13}$ bacteriophage per millilitre in buffer was mixed with adjuvant and injected into young albino rabbits (see Methods).

After the gamma-globulin fraction containing the antibodies had been separated from the rabbit serum and tagged with fluorescein, an aliquot of it was mixed with a sand-ground homogenate of $E$. coli $B$ cells and incubated at $37^{\circ} \mathrm{C}$. for one hour. After centrifugation to remove the sand, bacterial debris, and non-specific conjugated materials, the supernatant fluorescent antibody fraction was used to complex with $\mathrm{T}_{2} \mathrm{r}+$ bacteriophages.

An aliquot of freshly prepared stock of $T_{2} r+$ was diluted to $1 \times 10^{11}$ bacteriophage per millilitre on the basis of phage assay. This stock was further carefully diluted to other concentrations in buffer.

To each tube containing $2 \mathrm{ml}$. of a specific concentration of bacteriophage, $0.3 \mathrm{ml}$. of the treated fluorescent conjugate was added. The samples were then incubated at $37^{\circ} \mathrm{C}$. for 60 minutes to allow the antigen-antibody reaction to take place and a precipitate to form.

The samples were then centrifuged at $3,500 \mathrm{~g}$ for 15 minutes, the supernatants were poured off, and the precipitates (not macroscopically visible in the lowest concentration samples) were resuspended in $2 \mathrm{ml} .0 .1 \mathrm{M}$ phosphate buffer $(0.15 \mathrm{M}$ in $\mathrm{NaCl})$ at $p \mathrm{H} \mathrm{7.2}$. This washing step was repeated a second time.

The centrifugation was repeated a third time and this time the precipitates were dissolved in $2 \mathrm{ml}$. of $0.01 \mathrm{~N}$ $\mathrm{NaOH}$ which dissolved the precipitates and made the fluorescence homogeneous. $\mathrm{NaOH}$ of low fluorescence was used throughout this work.

Fluorescence readings of the various $T_{2}$ concentrations were made either in a Farrand spectrofluorometer or in a Turner spectrofluorometer. In the Farrand instrument, curves were run which indicated an excitation peak at $325 \mathrm{~m} \mu$ when the fluorescence wavelength was held $\vec{\infty}$ constant near $500 \mathrm{~m} \mu$. With the excitation wavelength set $\dot{\circ}$ at $325 \mathrm{~m} \mu$, an emission maximum was found near 520 $\mathrm{m} \mu$. With this instrument, all readings were taken at these settings. With the Turner spectrofluorometer, various filter combinations were used, but one that gave consistent results and was more sensitive than many of the others was the no. 7-60 and no. 8 filter combination for excitation and emission respectively.

In the first group of experiments, the concentration of $T_{2}$ was limited to values less than or equal to $1 \times 10^{11}$ phage per ml. Results of one of these experiments are illustrated in Figure 1. The points were found to lie in a straight line. In a second group of experiments at higher $T_{2}$ concentrations, the points lay on a smooth curve which decreased in slope as the concentration of bacteriophage increased.

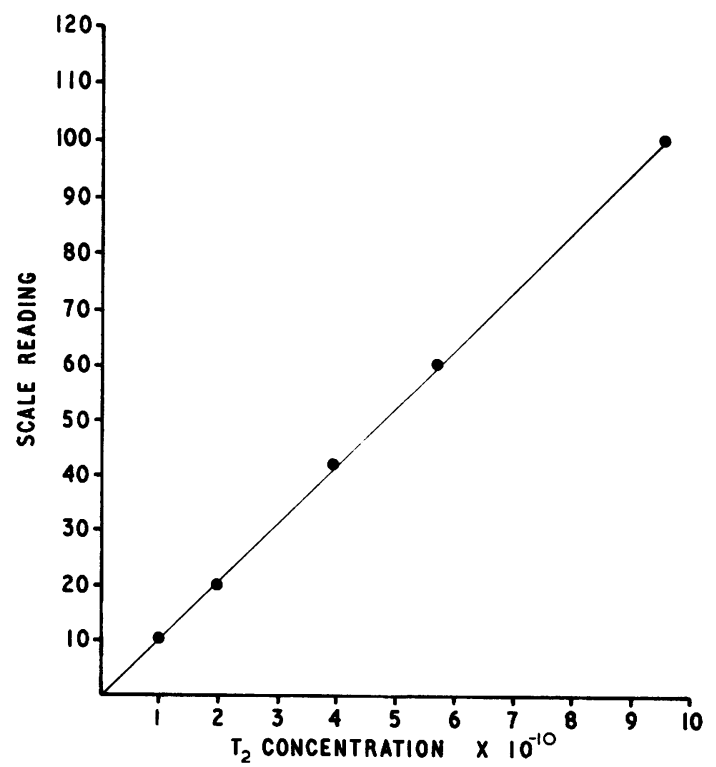

FIG. 1. Curve showing the relationship between the degree of fluorescence and $T_{2}$ phage concentration. 
EXPERIMENT USING BACTERIOPHAGE-INFECTED CELLS A second set of experiments was performed in order to test the method in the presence of non-specific proteins. A culture of Escherichia coli B was grown in M-9 medium (Anderson, 1946) to a concentration of $8 \times 10^{3}$ bacteria per ml. and purified $T_{2} r+$ were added at zero time to give a phage to bacteria ratio of $5: 1$.

At various times after infection, $2 \mathrm{ml}$. samples of phageinfected bacteria were withdrawn and quick-frozen in plastic tubes at dry ice temperatures. The tubes were stored frozen until the fluorescent antibody was prepared for conjugation.

After the material in the tubes had been melted, the tubes were placed in a Raytheon 250 watt, 10 kilocycle sonic oscillator until all remaining bacteria had been disrupted. The purpose of this procedure was to make the specific antigen available for conjugation with the fluorescent ant.body, since under ordinary conditions the $T_{2}$ coat protein would not be available until after the end of the latent period upon lysis of the bacteria.

To each tube containing the $2 \mathrm{ml}$. sample, $0.3 \mathrm{ml}$. of treated fluorescent conjugate was added as in the previous experiment. The tubes were then treated stepwise according to the method outlined there. Standards consisting of five known $T_{2}$ bacteriophage concentrations (two-fold dilutions) were run simultaneously in order to provide a basis for converting the fluorometer readings for the phage-infected cells into units of phage protein. Non-immune controls yielded results essentially equiva-

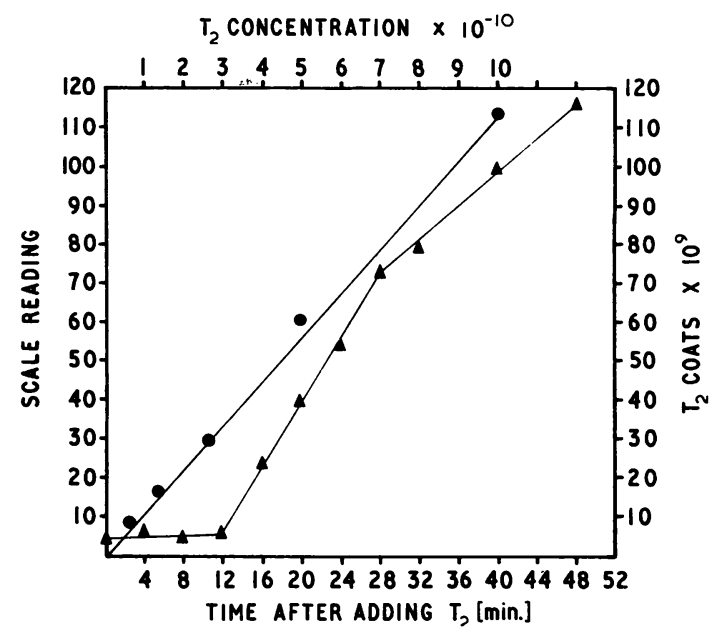

FIG. 2. Assay for $T_{2}$ coat protein at various times after infection of $\mathrm{E}$. coli with $T_{2}$. Calibration curve of fluorescence scale readings (left ordinate) for known $T_{2}$ concentrations (upper abscissa). $\Delta$ Curve showing the quantitative relationship between degree of fluorescence and concentration of protein coats. Points on the curve were determined by converting the fluorescence scale readings to concentration of $T_{2}$ coats (right ordinate) by use of the calibration curve, and plotting these against times after infection (lower abscissa). lent to the $0.01 \mathrm{~N} \mathrm{NaOH}$ blanks. The results of one such experiment are shown in Figure 2.

The five points determined using readings from the known $T_{2}$ concentrations are plotted using the left ordinate and upper abscissa, and the best straight line is plotted through these five points. This then represents the calibration curve for the experimental unknown readings taken at the same time.

With the use of this calibration curve, scale reading values for the unknown samples collected at various times after infection have been converted into units of $T_{2}$ coats. The other curve is plotted from this data, using the lower abscissa and right ordinate in Figure 2.

The plotted points indicate a horizontal straight line for approximately the first 12 minutes foll swing $\mathrm{T}_{2}$ infection followed by a rapid increase in the concentration of bacteriophage coats after 12 minutes. This corresponds closely to the appearance of active intracellular $\mathrm{T}_{2}$ following infection (Nutter and Sinsheimer, 1959).

\section{DISCUSSION}

Two points of interest are noteworthy in the second set of experiments. First, after the specific fluorescein-tagged antibody has been adsorbed with homogenate consisting of the host cells, or all the non-viral proteins in the system, the unknown points lie on relatively smooth curves and represent well the amounts of specific antigen for which assay is being made. One indication of this in Fig. 2 is the fact that the concentration of $T_{2}$ coats for the first several minutes of the experiment is found to be approximately $4 \times 10^{9}$ per $\mathrm{ml}$. This figure corresponds closely to the initial concentration of infecting $T_{2}$ bacteriophage, which from the data given previously for the experiment yields a figure of $4 \times 10^{9}$ infecting $\mathrm{T}_{2}$ per millilitre $(E$. coli concentration $=$ $8 \times 10^{8}$ per ml., multiplicity of infection $=5 \mathrm{~T}_{2}$ per $E$. coli).

The second point concerns the sensitivity of the technique. With the technique of Lowry et. al. (1951) for the determination of total protein as used in our laboratory, the minimum concentration of protein recommended is approximately 20 micrograms per $\mathrm{ml}$. Using the techniques and data from the second experiment, and the value of $2.4 \times 10^{-16}$ grams of protein per $T_{2}$ particle, it may be seen that the amounts of specific protein measurable here are less than $1 \mu \mathrm{g}$. per $\mathrm{ml}$. With the aid of high sensitivity attachments, made for certain of the spectrofluorometers and other filter combinations, it is likely that the figure might be dropped to less than $0 \cdot 1 \mu \mathrm{g}$. per ml.

Other applications of this quantitative fluorescent antibody technique will be published elsewhere. 
The authors wish to thank Dr. Jack D. Zwemer for helpful suggestions regarding the preparation of the antibody stocks.

\section{REFERENCES}

Adams, M. H. (1950). Meth. med. Res., 2, 1.

Anderson, E. H. (1946). Proc. nat. Acad. Sci. (Wash.), 32, 120.

Coons, A. H., and Kaplan, M. H. (1950). J. exp. Med., 81, 1.

Dubert, J. M., Slizewicz, P., Rebeyrotte, P., and Machebouef, M. (1953). Ann. Inst. Pasteur, 84, 370.

Fraser, D., and Jerrel, E. A. (1953). J. biol. Chem., 205, 291.

Lowry, O. H., Rosebrough, N. J., Farr, A. L., and Randall, R. J. (1951). Ibid., 193, 265.

Nutter, R. L., and Sinsheimer, R. L. (1959). Virology, 7, 276.

Riggs, J. L., Seiwald, R. J., Burckhalter, J. H., Downs, C. M., and Metcalf, T. G. (1958). Amer. J. Pathol., 34, 1081.

APPENDIX

SUMMARY OF THE TECHNIQUE

1 Secure, by regular means, antibodies to the particular protein to be assayed.
2 Conjugate the antibody preparation with fluorescein isothiocyanate followed by gel filtration to remove unbound fluorescent material.

3 To prevent non-specific reactions, incubate the labelled conjugate with a finely-ground, well-chosen, tissue suspension and recover the supernatant after centrifugation.

4 To $2 \mathrm{ml}$. samples containing the specific protein (in available form) to be assayed, add $0.3 \mathrm{ml}$. of treated fluorescein labelled antibody. (Approximate antibody protein concentration $5 \mathrm{mg} . / \mathrm{ml}$.)

5 Incubate the tubes at $37^{\circ} \mathrm{C}$. for 60 minutes.

6 Centrifuge the tubes at $3,500 \mathrm{~g}$ for 15 minutes. Pour off the supernatant and resuspend the precipitates in $2 \mathrm{ml}$. of buffer.

7 Repeat step 6.

8 Repeat the centrifugation a third time and resuspend the precipitates in $2 \mathrm{ml}$. of $0.01 \mathrm{~N} \mathrm{NaOH}$, which dissolves the precipitates and makes the fluorescence homogeneous.

9 Read the fluorescence of each sample in the spectrofluorometer using appropriate standards.

\section{Reports and Bulletins prepared by the Association of Clinical Biochemists}

The following reports and bulletins are published by the Association of Clinical Biochemists. They may be obtained from Mr. J. T. Ireland, Biochemistry Laboratory, Alder Hey Children's Hospital, Liverpool, 12. The prices include postage, but airmail will be charged extra.

\section{SCIENTIFIC REPORTS}

1 Colorimeters with Flow Through Cells. A Critical Assessment of 4 Instruments. 1965. P. M. G. BROUGHTON and C. RILEY. 13s 6d.

\section{TECHNICAL BULLETINS}

1 Data Sheet on Control Sera. July 1964. 1s.

2 A Report on the Enzyme Questionnaire Circulated by the Scientific Committee. December 1964. A. H. GOWENLOCK. $1 \mathrm{~s}$.

3 Non-recording Spectrophotometers for the Visible and Ultraviolet Ranges. A comparative table of instru- ments available in Great Britain. May 1965. A. H. $D$ GOWENLOCK, P. C. NICHOLAS, and J. H. WILKINSON. 을. 1s. 6d.

4 Control Solutions for Clinical Biochemistry. June 1965. P. M. G. BROUGHTON and A. H. GOWENLOCK. 1s. 6 d.

5 Recording Spectrophotometers. A comparative list of low-priced instruments readily available in Britain. July 1965. P. SEWELL. 2s. 6d.

6 A guide to Automatic Pipettes. A list of more than 100 instruments compiled from manufacturers' literature. August 1965. P. M. G. BROUGHTON. 5s.

7 Variability Between AutoAnalyzer Modules. August 1965. B. E. NORTHAM. 1s 6d. 